\title{
Review \\ The Role of Interleukin 18/Interleukin 18-Binding Protein in Adult-Onset Still's Disease and Systemic Juvenile Idiopathic Arthritis
}

\author{
Charlotte Girard-Guyonvarc' ${ }^{1, *}$, Mathilde Harel ${ }^{1,2}$ and Cem Gabay ${ }^{1,2}$ \\ 1 Division of Rheumatology, Department of Medicine, University Hospital of Geneva, 1206 Geneva, \\ Switzerland; mathilde.harel@unige.ch (M.H.); cem.gabay@unige.ch (C.G.) \\ 2 Department of Pathology and Immunology, School of Medicine, University of Geneva, \\ 1206 Geneva, Switzerland \\ * Correspondence: charlotte.girard@hcuge.ch
}

check for updates

Citation: Girard-Guyonvarc'h, C.; Harel, M.; Gabay, C. The Role of Interleukin 18/Interleukin 18-Binding Protein in Adult-Onset Still's Disease and Systemic Juvenile Idiopathic Arthritis. J. Clin. Med. 2022, 11, 430. https://doi.org/ $10.3390 / j \mathrm{~cm} 11020430$

Academic Editors: Jamilloux Yvan and Mathieu Gerfaud-Valentin

Received: 30 November 2021 Accepted: 10 January 2022

Published: 15 January 2022

Publisher's Note: MDPI stays neutral with regard to jurisdictional claims in published maps and institutional affiliations.

Copyright: (C) 2022 by the authors. Licensee MDPI, Basel, Switzerland. This article is an open access article distributed under the terms and conditions of the Creative Commons Attribution (CC BY) license (https:// creativecommons.org/licenses/by/ $4.0 /)$.

\begin{abstract}
Interleukin 18 (IL-18) is a pro-inflammatory cytokine of the IL-1 family, whose activity is tightly controlled at the level of production, as well as signalization. Notably, it is buffered by its natural inhibitor, IL-18 binding protein (IL-18BP), which is massively present in circulation in normal and in most pathological conditions, thus preventing harmful pro-inflammatory systemic effects of IL-18. IL-18 has long been considered to be involved in the pathophysiology of various inflammatory diseases. However, a first clinical trial using recombinant IL-18BP for the treatment of rheumatoid arthritis and psoriasis gave disappointing results. Direct measurements of unbound, bioactive, free form of circulating IL-18 demonstrated that IL-18 was more specifically involved in adult-onset Still's disease (AOSD) and systemic juvenile idiopathic arthritis (sIIA) but also in their most severe complication, macrophage activation syndrome (MAS). More importantly, administration of recombinant IL-18BP to patients with AOSD, and sJIA with MAS, showed promising results. This review summarizes available data regarding IL-18 and IL-18BP in AOSD and sJIA in mouse models and humans and shows the importance of IL-18/IL-18BP imbalance in these conditions, leading to the conclusion that IL-18, particularly free IL-18, may be a useful biomarker in these diseases and an interesting therapeutic target.
\end{abstract}

Keywords: interleukin 18; interleukin 18-binding protein; adult-onset Still's disease; systemic juvenile idiopathic arthritis; macrophage activation syndrome

\section{Introduction}

Among other biological markers, interleukin 18 (IL-18) appears as a reasonable candidate for a better understanding of adult-onset Still's disease (AOSD) and systemic juvenile idiopathic arthritis (sJIA) pathophysiology, evaluation of disease activity, and therapeutic approaches. In this review, we will make a brief presentation of IL-18 and IL-18 binding protein (IL-18BP) biology, summarize the fundamental and translational work that has been conducted in the last two decades in this topic, and, finally, state how IL-18 and IL-18BP could be used in clinical practice, for the management of AOSD and sJIA.

\section{Interleukin 18, Interleukin 18-Binding Protein, and the Interleukin 18/Interleukin 18-Binding Protein Balance}

\subsection{Interleukin-18: Characterization, Structure, Maturation}

IL-18 is a pro-inflammatory cytokine that was first described as an IFN- $\gamma$-inducing factor [1]. It is constitutively expressed by various cell types, including monocytes/macrophages, dendritic cells, and epithelial cells [2]. It was suggested to be part of the IL-1 family of cytokines because of its $\beta$-pleated structure, which was shown to be similar to the one of IL-1 $\beta$ [3]. Likewise, IL-18 is translated as an immature protein containing an $\mathrm{N}$-terminus 
pro-domain that must be cleaved for full activity. Among other proteases, caspase-1, the cytosolic enzymatic effector of the inflammasome, has been proposed as the main effector of IL-18 maturation, especially in immune cells [2,4]. As for IL-1 $\beta$, IL-18 is released in the extra-cellular milieu in its bioactive form through pores formed by oligomerization of Gasdermin D, itself cleaved by caspase-1 [5].

\subsection{IL-18 Receptor, Signaling Pathways, and IL-18 Functions}

The IL-18 receptor (IL-18R) is a heterodimer composed of one binding chain, IL-18R $\alpha$, and one signaling chain, IL-18R $\beta$. IL-18R $\alpha$ (also known as IL-1R-related protein) is a receptor of the IL-1 family, which binds to IL-18 with low affinity [6]. IL-18R $\beta$ is the co-receptor of the IL-18R and is essential for IL-18 signaling [6]. Both subunits $\alpha$ and $\beta$ have been proposed to be co-expressed by T cells, dendritic cells, and NK cells, more generally, by competent IFN- $\gamma$-producing cells [7]. With IL-18, they form a high-affinity complex that transduces intracellular pro-inflammatory signals. Similar to receptors of the IL-1R family and Toll-like receptors (TLRs), the intracellular region of IL-18R $\beta$ contains a Toll/IL-1 receptor (TIR) domain that, upon IL-18/IL-18R complex formation, binds to the adaptor molecule myeloid differentiation factor (MyD)88 [8] to stimulate an intracellular signaling cascade. Downstream factors include IRAKs, TRAF6, and finally NF-kB [9]. IL-18 mainly targets CD8+ T-cells and NK cells, in collaboration with IL-12, to stimulate IFN- $\gamma$ production [10] and induce their activation [11,12]. IL-18 also triggers naïve CD4+ T cells differentiation into Th1 cells and IFN- $\gamma$ release. On the other hand, in the absence of IL-12, IL-18 was shown to promote Th2 rather than Th1 immune responses and, in combination with IL-23, to promote the Th17 pathway (Figure 1) [2,7,13]. Additional functions of IL-18 have been reported, including neutrophil activation and induction of nitric oxide synthesis and VCAM-1 expression [14-16].

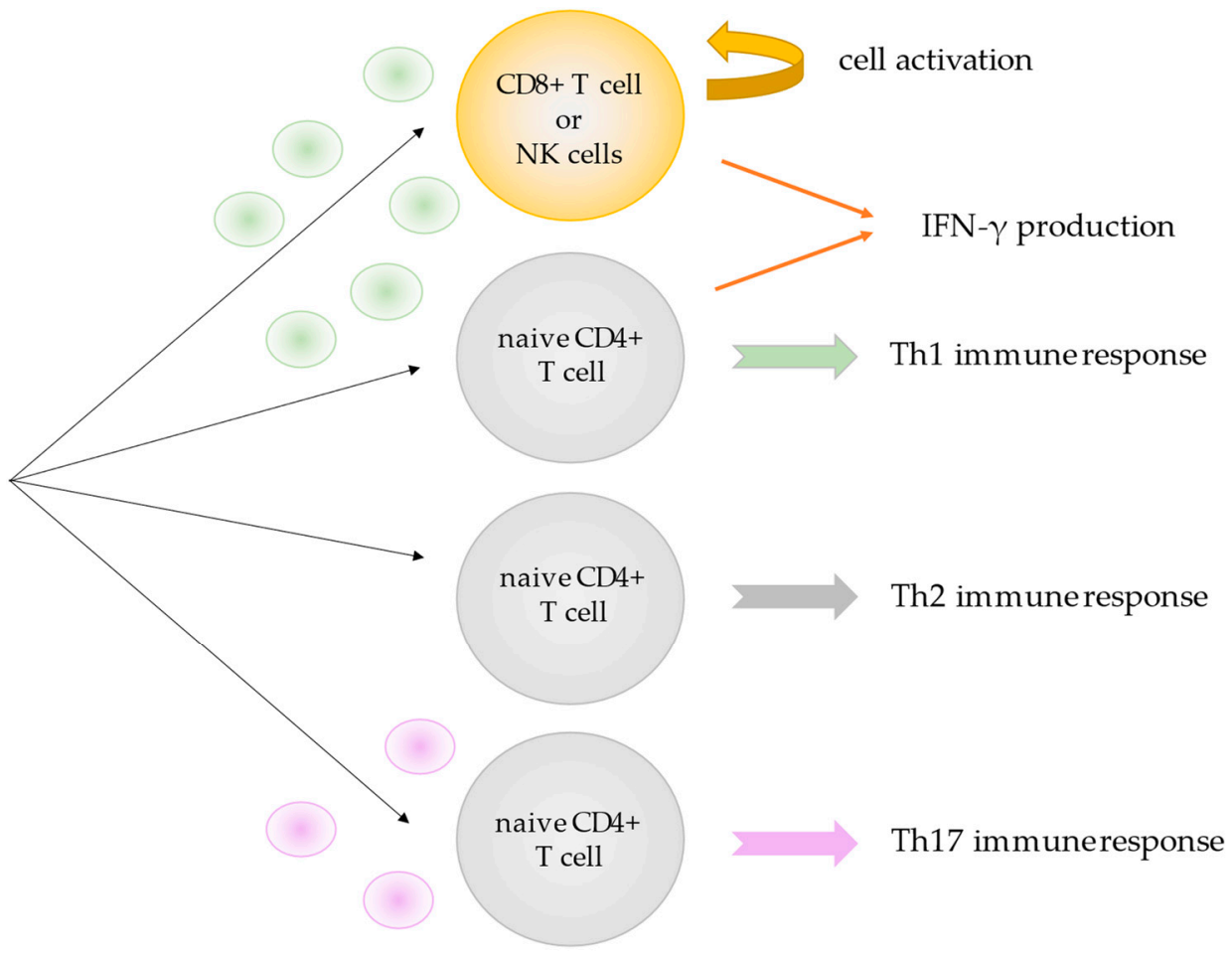

Figure 1. IL-18 functions depending on cytokine environment. IL: Interleukin; CD: cluster of differentiation; NK: natural killer; IFN: interferon. Th: T helper. 


\subsection{IL-18BP and Interaction with IL-18}

IL-18 bioactivity is not only regulated through caspase-1-dependent processing but also by the inhibitory effect of IL-18BP. IL-18BP was first identified in human urine when searching for an IL-18 soluble receptor [17]. It naturally binds mature IL-18 to form high-affinity complexes [18,19]. IL-18BP prevents IL-18 from binding to IL-18R and, thus, IL-18-induced IFN- $\gamma$ and other pro-inflammatory cytokines production $[17,20]$. IL-18BP has been shown to be expressed by various immune and non-immune cells in vitro and ex vivo, but the relevant cellular sources of IL-18BP are still unclear in vivo $[17,20]$. It was found to circulate in a 20-fold molar excess compared to IL-18 in healthy individuals [21]. Consequently, most of circulating IL-18 is bound to IL-18BP and thus inactive. IL-18BP is further upregulated by IFN- $\gamma$, which triggers a negative feedback loop in the IL18/Il-18BP balance $[22,23]$.

\subsection{IL-18 in Inflammatory Diseases: The Wrong Track}

IL-18 has been considered to play a pathological role in many diseases, according to the data derived from various animal models [24-28]. Furthermore, high circulating levels of IL-18 have been measured in a large number of inflammatory diseases [21,29-34], and IL-18 has been shown to be overexpressed in affected organs, such as the intestinal mucosa in Crohn's disease, the synovial tissue in rheumatoid arthritis, and the skin lesions in psoriasis [35-37]. Nonetheless, two clinical trials using recombinant IL-18BP (tadekinig alfa) failed to demonstrate any efficacy of IL-18 blockade in rheumatoid arthritis and psoriasis [38]. Indeed, it appears that, more than the total IL-18 levels, the amounts of free, IL-18BP-unbound, bioactive IL-18 are critical to consider when trying to decipher the role of IL-18 in the pathophysiology of one disease.

\section{IL-18 and IL-18BP in AOSD and sJIA}

AOSD was the first disease where free IL-18 circulating levels were proven to be significantly elevated, thanks to a specifically designed ELISA [19]. Indeed, until then, in some studies, free IL-18 concentrations had been indirectly calculated using the law of mass action, based on the IL-18BP and IL-18 levels, a 1:1 stoichiometry, and a dissociation constant $(\mathrm{Kd})$ of $400 \mathrm{pM}[21,29]$. Through BIAcore analyses, we showed that the binding affinity of IL-18BP to IL-18 was even higher than previously described [19]. Thus, preceding free IL-18 calculations may have been overestimated.

\subsection{IL-18 and IL-18BP in Mouse Models of SJIA and Macrophage Activation Syndrome}

In opposition to other inflammatory diseases, such as Crohn's disease or rheumatoid arthritis, data regarding IL-18 and IL-18BP in animal models are scarce. Avau et al. developed a model of systemic inflammatory syndrome compiling most manifestations of sJIA, including arthritis and macrophage activation syndrome (MAS), a well-known complication of sJIA and AOSD. This disease model is induced by injecting complete Freund's adjuvant in IFN- $\gamma$-KO mice. The authors did not find elevated levels of circulating IL-18, only increased IL-18 mRNA expression in lymph node cells (but not in blood cells), as compared to non-injected-IFN- $\gamma-\mathrm{KO}$ mice [39]. Kawane et al. found high serum levels of IL-18 in DNase II-null mice, a mouse model of MAS also displaying arthritis, but demonstrated that the development of arthritis in these mice was IL-18-independent [40]. Conversely, mice repeatedly subjected to TLR9 stimulation develop MAS in an IFN- $\gamma$-dependent and IL-18 manner [41]. Indeed, we showed that IL-18BP-deficient mice displayed a more severe phenotype than wild-type (WT) animals and that this was associated with the detection of circulating free IL-18 in IL-18BP-deficient but not in WT mice. In the same MAS model, we demonstrated that depletion of IL-18BP expression in either the radiosensitive or radioresistant compartment did not change the circulating levels of IL-18BP, suggesting that circulating IL-18BP levels are tightly regulated even when some important IL-18BP cellular sources are missing [23]. IL-18 blockade prevented the development of MAS in IL-18BP-deficient mice, the whole indicating that excessive IL-18 signaling is associated 
with severe manifestations of MAS and that endogenous IL-18BP plays a critical role in regulating IL-18-induced systemic responses [42].

\subsection{IL-18 and IL-18BP in AOSD and SJIA in Human}

For years, it has been reported that IL-18 circulating levels were significantly elevated in AOSD as compared to healthy subjects, other rheumatic diseases, or infections [43-46]. Similar findings were published in sJIA in comparison to healthy children, non-systemic juvenile idiopathic arthritis, or Kawaski disease [47-50]. In addition, IL-18 concentrations have been shown to be higher during the active phase of AOSD and sJIA than during disease remission [44-46,48,49]. Furthermore, IL-18 levels correlated with AOSD and sJIA disease activity markers, including ferritinemia and CRP [44-47]. Interestingly, extremely high IL-18 levels have been reported in sJIA patients with a history of MAS [51]. Shimizu et al. also demonstrated that sJIA patients who would later develop MAS had significantly higher IL-18 serum levels than patients who would not [52]. Moreover, higher IL-18 concentrations have been measured in AOSD and sJIA patients with MAS than patients with an active disease without MAS [53,54]. In addition, IL-18 expression was increased in different tissues of AOSD and sJIA patients, including skin, joints, liver, and lymph nodes [50,55-57]. Enhanced expression of IL-18 was also described in the bone marrow of a young patient with sJIA, who died with MAS [58].

Of note, polymorphisms in the promoter region of the IL18 gene have been associated with a risk of developing AOSD and sJIA. Diplotype S01/S01 was a major risk factor for susceptibility to AOSD but not to sJIA [59,60]. Nonetheless, sJIA patients carrying S01/S01 showed the highest IL-18 serum levels.

Remarkably, serum levels of IL-18BP were also significantly elevated in patients with active AOSD and sJIA as compared to healthy controls $[19,46,48,60]$. But no significant difference could be seen between active and inactive AOSD [19,61]. The IL-18/IL-18BP ratio was found to be higher in active sJIA than inactive sJIA patients and healthy controls [48]. More importantly, calculated free IL-18 levels were increased in AOSD and sJIA in comparison to controls, were higher during active than inactive disease, and correlated with markers of disease activity in AOSD [46,61].

By directly measuring IL-18BP-unbound, bioactive, free IL-18, we clearly demonstrated the specific imbalance of IL-18/IL-18BP in AOSD (Figure 2). Indeed, serum levels of free IL-18 were significantly higher in AOSD than in healthy subjects as well as in patients with active rheumatoid arthritis, systemic lupus erythematosus, ankylosing spondylitis, and psoriatic arthritis. Furthermore, we showed that free IL-18 serum levels were higher during active than inactive AOSD and correlated with CRP, ferritinemia, blood leucocyte count, and alanine amino transferase levels [19]. We also found extremely high free IL-18 concentrations in AOSD and sJIA patients with MAS [54,62]. In addition, we reported the case of an sJIA patient with MAS who responded favorably to IL-18 inhibition using tadekinig alfa (human recombinant IL-18BP) [62]. In AOSD, the role of free bioactive IL-18 was further confirmed by a first phase II clinical trial in patients with refractory AOSD who were treated with tadekinig alfa. Half of the patients achieved a response after 3 weeks, as defined by normalization of body temperature and decrease in CRP (by $50 \%$ of the baseline levels or $<5 \mathrm{mg} / \mathrm{L}$ ) [63]. We also reported the case of one patient with AOSD, treated with tadekinig alfa, whose high serum levels of free IL-18 became undetectable $2 \mathrm{~h}$ after the first subcutaneous administration of IL-18BP, remained low while in disease remission under therapy, and then increased when tadekinig alfa was discontinued, in parallel to AOSD relapse [64]. 


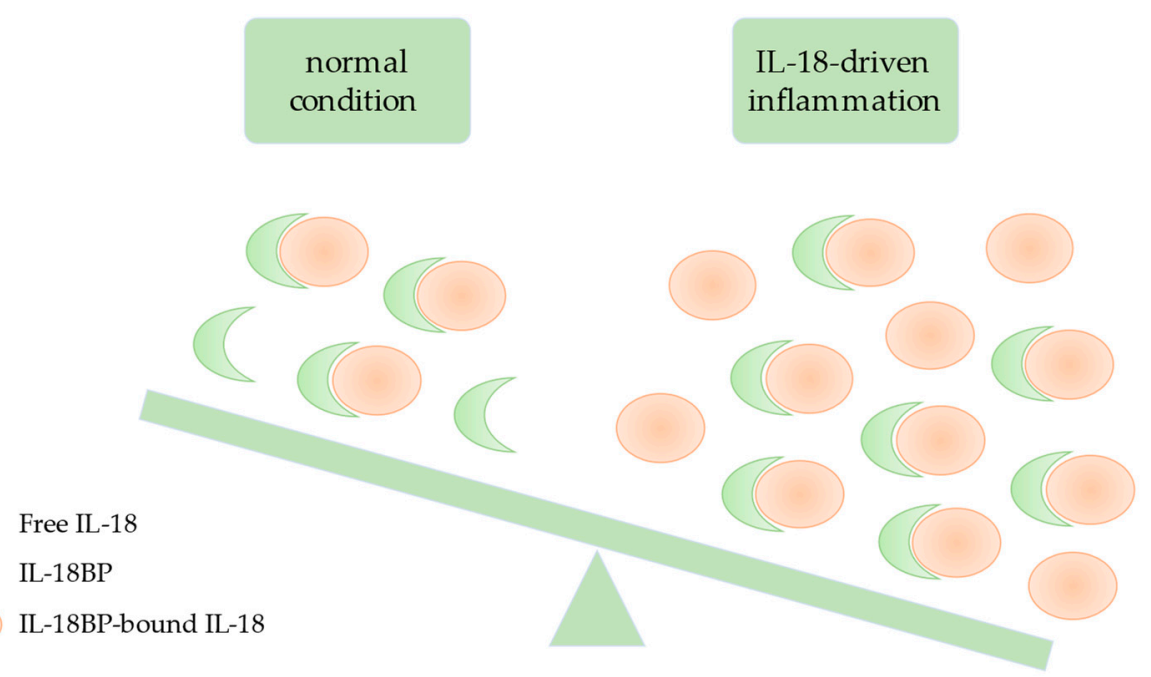

Figure 2. Schematic representation of IL-18/IL-18BP imbalance in AOSD and sJIA. In healthy individuals and most inflammatory diseases, elevated concentrations of IL-18BP and its high affinity for IL-18 causes basically all IL-18 to be buffered by IL-18BP, thus inactive (since unable to bind to IL-18 receptor) (left part of the figure). During active AOSD and sJIA, despite increased circulating levels of IL-18BP, its buffering capacities are overwhelmed by more elevated levels of IL-18 (right part of the figure). Some circulating IL-18 remains unbound to IL-18BP, meaning "free" and biologically active.

\section{Conclusions}

More than other inflammatory conditions, AOSD, sJIA, and their dreadful complication MAS are thought to be IL-18-driven. Indeed, it appears that in these diseases, the buffering capacities of IL-18BP are overwhelmed by markedly elevated IL-18 concentrations. A failure of NK cells to respond to IL-18 and produce IFN- $\gamma$, leading to decreased IL-18BP levels, has been hypothesized to explain this IL-18/IL-18BP imbalance [65]. More than total IL-18 levels, free IL-18 concentrations appear as a useful marker of AOSD, sJIA, and MAS, that could help physicians to establish the diagnosis of these challenging conditions. Furthermore, IL-18 may be an interesting therapeutic target in AOSD and SJIA, with or without MAS. A phase III clinical trial using tadekinig alfa in active AOSD is about to begin.

Author Contributions: Writing—original draft preparation, C.G.-G.; writing—review and editing, C.G.-G., M.H. and C.G. All authors have read and agreed to the published version of the manuscript.

Funding: C.G. is supported by a Swiss National Science Foundation grant (No 310030B_201269) and a grant from the Rheumasearch Foundation.

Institutional Review Board Statement: Not applicable.

Informed Consent Statement: Not applicable.

Data Availability Statement: Not applicable.

Conflicts of Interest: C.G. has received research funding and consulting fees from AB2 Bio Ltd. The funders had no role in the writing of the manuscript. C.G.-G. and M.H. declare no conflict of interest.

\section{References}

1. Nakamura, K.; Okamura, H.; Nagata, K.; Komatsu, T.; Tamura, T. Purification of a Factor Which Provides a Costimulatory Signal for Gamma Interferon Production. Infect. Immun. 1993, 61, 64-70. [CrossRef]

2. Dinarello, C.A.; Novick, D.; Kim, S.; Kaplanski, G. Interleukin-18 and IL-18 Binding Protein. Front. Immunol. 2013, 4, 289. [CrossRef]

3. Bazan, J.F.; Timans, J.C.; Kastelein, R.A. A Newly Defined Interleukin-1? Nature 1996, 379, 591. [CrossRef] 
4. Gu, Y.; Kuida, K.; Tsutsui, H.; Ku, G.; Hsiao, K.; Fleming, M.A.; Hayashi, N.; Higashino, K.; Okamura, H.; Nakanishi, K.; et al. Activation of Interferon-Gamma Inducing Factor Mediated by Interleukin-1beta Converting Enzyme. Science 1997, 275, 206-209. [CrossRef]

5. Heilig, R.; Dick, M.S.; Sborgi, L.; Meunier, E.; Hiller, S.; Broz, P. The Gasdermin-D Pore Acts as a Conduit for IL-1 $\beta$ Secretion in Mice. Eur. J. Immunol. 2018, 48, 584-592. [CrossRef] [PubMed]

6. Torigoe, K.; Ushio, S.; Okura, T.; Kobayashi, S.; Taniai, M.; Kunikata, T.; Murakami, T.; Sanou, O.; Kojima, H.; Fujii, M.; et al. Purification and Characterization of the Human Interleukin-18 Receptor. J. Biol. Chem. 1997, 272, 25737-25742. [CrossRef] [PubMed]

7. Kaplanski, G. Interleukin-18: Biological Properties and Role in Disease Pathogenesis. Immunol. Rev. 2018, 281, 138-153. [CrossRef]

8. Boraschi, D.; Tagliabue, A. The Interleukin-1 Receptor Family. Semin. Immunol. 2013, 25, 394-407. [CrossRef]

9. Sedimbi, S.K.; Hägglöf, T.; Karlsson, M.C.I. IL-18 in Inflammatory and Autoimmune Disease. Cell. Mol. Life Sci. CMLS 2013, 70, 4795-4808. [CrossRef]

10. Fehniger, T.A.; Shah, M.H.; Turner, M.J.; VanDeusen, J.B.; Whitman, S.P.; Cooper, M.A.; Suzuki, K.; Wechser, M.; Goodsaid, F.; Caligiuri, M.A. Differential Cytokine and Chemokine Gene Expression by Human NK Cells Following Activation with IL-18 or IL-15 in Combination with IL-12: Implications for the Innate Immune Response. J. Immunol. 1999, 162, 4511-4520. [PubMed]

11. Okamoto, I.; Kohno, K.; Tanimoto, T.; Ikegami, H.; Kurimoto, M. Development of CD8+ Effector T Cells Is Differentially Regulated by IL-18 and IL-12. J. Immunol. 1999, 162, 3202-3211.

12. Tomura, M.; Zhou, X.Y.; Maruo, S.; Ahn, H.J.; Hamaoka, T.; Okamura, H.; Nakanishi, K.; Tanimoto, T.; Kurimoto, M.; Fujiwara, H. A Critical Role for IL-18 in the Proliferation and Activation of NK1.1+ CD3- Cells. J. Immunol. 1998, 160, 4738-4746.

13. Hoshino, T.; Wiltrout, R.H.; Young, H.A. IL-18 Is a Potent Coinducer of IL-13 in NK and T Cells: A New Potential Role for IL-18 in Modulating the Immune Response. J. Immunol. 1999, 162, 5070-5077. [PubMed]

14. Leung, B.P.; Culshaw, S.; Gracie, J.A.; Hunter, D.; Canetti, C.A.; Campbell, C.; Cunha, F.; Liew, F.Y.; McInnes, I.B. A Role for IL-18 in Neutrophil Activation. J. Immunol. 2001, 167, 2879-2886. [CrossRef] [PubMed]

15. Gracie, J.A.; Forsey, R.J.; Chan, W.L.; Gilmour, A.; Leung, B.P.; Greer, M.R.; Kennedy, K.; Carter, R.; Wei, X.Q.; Xu, D.; et al. A Proinflammatory Role for IL-18 in Rheumatoid Arthritis. J. Clin. Investig. 1999, 104, 1393-1401. [CrossRef]

16. Vidal-Vanaclocha, F.; Fantuzzi, G.; Mendoza, L.; Fuentes, A.M.; Anasagasti, M.J.; Martín, J.; Carrascal, T.; Walsh, P.; Reznikov, L.L.; Kim, S.H.; et al. IL-18 Regulates IL-1beta-Dependent Hepatic Melanoma Metastasis via Vascular Cell Adhesion Molecule-1. Proc. Natl. Acad. Sci. USA 2000, 97, 734-739. [CrossRef]

17. Novick, D.; Kim, S.H.; Fantuzzi, G.; Reznikov, L.L.; Dinarello, C.A.; Rubinstein, M. Interleukin-18 Binding Protein: A Novel Modulator of the Th1 Cytokine Response. Immunity 1999, 10, 127-136. [CrossRef]

18. Kim, S.H.; Eisenstein, M.; Reznikov, L.; Fantuzzi, G.; Novick, D.; Rubinstein, M.; Dinarello, C.A. Structural Requirements of Six Naturally Occurring Isoforms of the IL-18 Binding Protein to Inhibit IL-18. Proc. Natl. Acad. Sci. USA 2000, 97, 1190-1195. [CrossRef] [PubMed]

19. Girard, C.; Rech, J.; Brown, M.; Allali, D.; Roux-Lombard, P.; Spertini, F.; Schiffrin, E.J.; Schett, G.; Manger, B.; Bas, S.; et al. Elevated Serum Levels of Free Interleukin-18 in Adult-Onset Still's Disease. Rheumatol. Oxf. Engl. 2016, 55, 2237-2247. [CrossRef]

20. Aizawa, Y.; Akita, K.; Taniai, M.; Torigoe, K.; Mori, T.; Nishida, Y.; Ushio, S.; Nukada, Y.; Tanimoto, T.; Ikegami, H.; et al. Cloning and Expression of Interleukin-18 Binding Protein. FEBS Lett. 1999, 445, 338-342. [CrossRef]

21. Novick, D.; Schwartsburd, B.; Pinkus, R.; Suissa, D.; Belzer, I.; Sthoeger, Z.; Keane, W.F.; Chvatchko, Y.; Kim, S.H.; Fantuzzi, G.; et al. A Novel IL-18BP ELISA Shows Elevated Serum IL-18BP in Sepsis and Extensive Decrease of Free IL-18. Cytokine 2001, 14, 334-342. [CrossRef] [PubMed]

22. Paulukat, J.; Bosmann, M.; Nold, M.; Garkisch, S.; Kämpfer, H.; Frank, S.; Raedle, J.; Zeuzem, S.; Pfeilschifter, J.; Mühl, H. Expression and Release of IL-18 Binding Protein in Response to IFN-Gamma. J. Immunol. Baltim. Md 1950 2001, 167, 7038-7043. [CrossRef]

23. Harel, M.; Girard-Guyonvarc'h, C.; Rodriguez, E.; Palmer, G.; Gabay, C. Production of IL-18 Binding Protein by Radiosensitive and Radioresistant Cells in CpG-Induced Macrophage Activation Syndrome. J. Immunol. Baltim. Md 1950 2020, 205, 1167-1175. [CrossRef]

24. Plater-Zyberk, C.; Joosten, L.A.; Helsen, M.M.; Sattonnet-Roche, P.; Siegfried, C.; Alouani, S.; van De Loo, F.A.; Graber, P.; Aloni, S.; Cirillo, R.; et al. Therapeutic Effect of Neutralizing Endogenous IL-18 Activity in the Collagen-Induced Model of Arthritis. J. Clin. Invest. 2001, 108, 1825-1832. [CrossRef]

25. Sivakumar, P.V.; Westrich, G.M.; Kanaly, S.; Garka, K.; Born, T.L.; Derry, J.M.J.; Viney, J.L. Interleukin 18 Is a Primary Mediator of the Inflammation Associated with Dextran Sulphate Sodium Induced Colitis: Blocking Interleukin 18 Attenuates Intestinal Damage. Gut 2002, 50, 812-820. [CrossRef] [PubMed]

26. Bossù, P.; Neumann, D.; Del Giudice, E.; Ciaramella, A.; Gloaguen, I.; Fantuzzi, G.; Dinarello, C.A.; Di Carlo, E.; Musiani, P.; Meroni, P.L.; et al. IL-18 CDNA Vaccination Protects Mice from Spontaneous Lupus-like Autoimmune Disease. Proc. Natl. Acad. Sci. USA 2003, 100, 14181-14186. [CrossRef]

27. Millward, J.M.; Løbner, M.; Wheeler, R.D.; Owens, T. Inflammation in the Central Nervous System and Th17 Responses Are Inhibited by IFN-Gamma-Induced IL-18 Binding Protein. J. Immunol. 2010, 185, 2458-2466. [CrossRef] 
28. Kang, M.-J.; Homer, R.J.; Gallo, A.; Lee, C.G.; Crothers, K.A.; Cho, S.J.; Rochester, C.; Cain, H.; Chupp, G.; Yoon, H.J.; et al. IL-18 Is Induced and IL-18 Receptor Alpha Plays a Critical Role in the Pathogenesis of Cigarette Smoke-Induced Pulmonary Emphysema and Inflammation. J. Immunol. 2007, 178, 1948-1959. [CrossRef]

29. Ludwiczek, O.; Kaser, A.; Novick, D.; Dinarello, C.A.; Rubinstein, M.; Tilg, H. Elevated Systemic Levels of Free Interleukin-18 (IL-18) in Patients with Crohn's Disease. Eur. Cytokine Netw. 2005, 16, 27-33. [PubMed]

30. Bresnihan, B.; Roux-Lombard, P.; Murphy, E.; Kane, D.; FitzGerald, O.; Dayer, J.-M. Serum Interleukin 18 and Interleukin 18 Binding Protein in Rheumatoid Arthritis. Ann. Rheum. Dis. 2002, 61, 726-729. [CrossRef]

31. Wong, C.K.; Li, E.K.; Ho, C.Y.; Lam, C.W. Elevation of Plasma Interleukin-18 Concentration Is Correlated with Disease Activity in Systemic Lupus Erythematosus. Rheumatol. Oxf. Engl. 2000, 39, 1078-1081. [CrossRef] [PubMed]

32. Gangemi, S.; Merendino, R.A.; Guarneri, F.; Minciullo, P.L.; DiLorenzo, G.; Pacor, M.; Cannavò, S.P. Serum Levels of Interleukin-18 and s-ICAM-1 in Patients Affected by Psoriasis: Preliminary Considerations. J. Eur. Acad. Dermatol. Venereol. JEADV 2003, 17, 42-46. [CrossRef] [PubMed]

33. Imaoka, H.; Gauvreau, G.M.; Watson, R.M.; Smith, S.G.; Dua, B.; Baatjes, A.J.; Howie, K.; Hoshino, T.; Killian, K.J.; Aizawa, H.; et al. Interleukin-18 and Interleukin-18 Receptor- $\alpha$ Expression in Allergic Asthma. Eur. Respir. J. 2011, 38, 981-983. [CrossRef] [PubMed]

34. Wang, J.; Liu, X.; Xie, M.; Xie, J.; Xiong, W.; Xu, Y. Increased Expression of Interleukin-18 and Its Receptor in Peripheral Blood of Patients with Chronic Obstructive Pulmonary Disease. COPD 2012, 9, 375-381. [CrossRef]

35. Pizarro, T.T.; Michie, M.H.; Bentz, M.; Woraratanadharm, J.; Smith, M.F.; Foley, E.; Moskaluk, C.A.; Bickston, S.J.; Cominelli, F. IL-18, a Novel Immunoregulatory Cytokine, Is up-Regulated in Crohn's Disease: Expression and Localization in Intestinal Mucosal Cells. J. Immunol. 1999, 162, 6829-6835.

36. Tanaka, M.; Harigai, M.; Kawaguchi, Y.; Ohta, S.; Sugiura, T.; Takagi, K.; Ohsako-Higami, S.; Fukasawa, C.; Hara, M.; Kamatani, N. Mature Form of Interleukin 18 Is Expressed in Rheumatoid Arthritis Synovial Tissue and Contributes to Interferon-Gamma Production by Synovial T Cells. J. Rheumatol. 2001, 28, 1779-1787. [PubMed]

37. Companjen, A.; van der Wel, L.; van der Fits, L.; Laman, J.; Prens, E. Elevated Interleukin-18 Protein Expression in Early Active and Progressive Plaque-Type Psoriatic Lesions. Eur. Cytokine Netw. 2004, 15, 210-216. [PubMed]

38. Tak, P.P.; Bacchi, M.; Bertolino, M. Pharmacokinetics of IL-18 Binding Protein in Healthy Volunteers and Subjects with Rheumatoid Arthritis or Plaque Psoriasis. Eur. J. Drug Metab. Pharmacokinet. 2006, 31, 109-116. [CrossRef] [PubMed]

39. Avau, A.; Mitera, T.; Put, S.; Put, K.; Brisse, E.; Filtjens, J.; Uyttenhove, C.; Van Snick, J.; Liston, A.; Leclercq, G.; et al. Systemic Juvenile Idiopathic Arthritis-like Syndrome in Mice Following Stimulation of the Immune System with Freund's Complete Adjuvant: Regulation by Interferon- $\gamma$. Arthritis Rheumatol. Hoboken NJ USA 2014, 66, 1340-1351. [CrossRef]

40. Kawane, K.; Tanaka, H.; Kitahara, Y.; Shimaoka, S.; Nagata, S. Cytokine-Dependent but Acquired Immunity-Independent Arthritis Caused by DNA Escaped from Degradation. Proc. Natl. Acad. Sci. USA 2010, 107, 19432-19437. [CrossRef]

41. Behrens, E.M.; Canna, S.W.; Slade, K.; Rao, S.; Kreiger, P.A.; Paessler, M.; Kambayashi, T.; Koretzky, G.A. Repeated TLR9 Stimulation Results in Macrophage Activation Syndrome-like Disease in Mice. J. Clin. Invest. 2011, 121, 2264-2277. [CrossRef] [PubMed]

42. Girard-Guyonvarc'h, C.; Palomo, J.; Martin, P.; Rodriguez, E.; Troccaz, S.; Palmer, G.; Gabay, C. Unopposed IL-18 Signaling Leads to Severe TLR9-Induced Macrophage Activation Syndrome in Mice. Blood 2018, 131, 1430-1441. [CrossRef]

43. Kawaguchi, Y.; Terajima, H.; Harigai, M.; Hara, M.; Kamatani, N. Interleukin-18 as a Novel Diagnostic Marker and Indicator of Disease Severity in Adult-Onset Still's Disease. Arthritis Rheum. 2001, 44, 1716-1717. [CrossRef]

44. Colafrancesco, S.; Priori, R.; Alessandri, C.; Perricone, C.; Pendolino, M.; Picarelli, G.; Valesini, G. IL-18 Serum Level in Adult Onset Still's Disease: A Marker of Disease Activity. Int. J. Inflamm. 2012, 2012, 156890. [CrossRef] [PubMed]

45. Priori, R.; Colafrancesco, S.; Alessandri, C.; Minniti, A.; Perricone, C.; Iaiani, G.; Palazzo, D.; Valesini, G. Interleukin 18: A Biomarker for Differential Diagnosis between Adult-Onset Still's Disease and Sepsis. J. Rheumatol. 2014, 41, 1118-1123. [CrossRef]

46. Jung, K.-H.; Kim, J.-J.; Lee, J.-S.; Park, W.; Kim, T.-H.; Jun, J.-B.; Yoo, D.H. Interleukin-18 as an Efficient Marker for Remission and Follow-up in Patients with Inactive Adult-Onset Still's Disease. Scand. J. Rheumatol. 2014, 43, 162-169. [CrossRef]

47. Maeno, N.; Takei, S.; Nomura, Y.; Imanaka, H.; Hokonohara, M.; Miyata, K. Highly Elevated Serum Levels of Interleukin-18 in Systemic Juvenile Idiopathic Arthritis but Not in Other Juvenile Idiopathic Arthritis Subtypes or in Kawasaki Disease: Comment on the Article by Kawashima et Al. Arthritis Rheum. 2002, 46, 2539-2541. [CrossRef]

48. Chen, O.; Shan, N.; Zhu, X.; Wang, Y.; Ren, P.; Wei, D.; Sun, R. The Imbalance of IL-18/IL-18BP in Patients with Systemic Juvenile Idiopathic Arthritis. Acta Biochim. Biophys. Sin. 2013, 45, 339-341. [CrossRef]

49. Jelusić, M.; Lukić, I.K.; Tambić-Bukovac, L.; Dubravcić, K.; Malcić, I.; Rudan, I.; Batinić, D. Interleukin-18 as a Mediator of Systemic Juvenile Idiopathic Arthritis. Clin. Rheumatol. 2007, 26, 1332-1334. [CrossRef]

50. Lotito, A.P.N.; Campa, A.; Silva, C.A.A.; Kiss, M.H.B.; Mello, S.B.V. Interleukin 18 as a Marker of Disease Activity and Severity in Patients with Juvenile Idiopathic Arthritis. J. Rheumatol. 2007, 34, 823-830.

51. Yasin, S.; Fall, N.; Brown, R.A.; Henderlight, M.; Canna, S.W.; Girard-Guyonvarc'h, C.; Gabay, C.; Grom, A.A.; Schulert, G.S. IL-18 as a Biomarker Linking Systemic Juvenile Idiopathic Arthritis and Macrophage Activation Syndrome. Rheumatol. Oxf. Engl. 2020, 59, 361-366. [CrossRef] 
52. Shimizu, M.; Nakagishi, Y.; Inoue, N.; Mizuta, M.; Ko, G.; Saikawa, Y.; Kubota, T.; Yamasaki, Y.; Takei, S.; Yachie, A. Interleukin-18 for Predicting the Development of Macrophage Activation Syndrome in Systemic Juvenile Idiopathic Arthritis. Clin. Immunol. Orlando Fla 2015, 160, 277-281. [CrossRef] [PubMed]

53. Inoue, N.; Shimizu, M.; Tsunoda, S.; Kawano, M.; Matsumura, M.; Yachie, A. Cytokine Profile in Adult-Onset Still's Disease: Comparison with Systemic Juvenile Idiopathic Arthritis. Clin. Immunol. Orlando Fla 2016, 169, 8-13. [CrossRef] [PubMed]

54. Weiss, E.S.; Girard-Guyonvarc'h, C.; Holzinger, D.; de Jesus, A.A.; Tariq, Z.; Picarsic, J.; Schiffrin, E.J.; Foell, D.; Grom, A.A.; Ammann, S.; et al. Interleukin-18 Diagnostically Distinguishes and Pathogenically Promotes Human and Murine Macrophage Activation Syndrome. Blood 2018, 131, 1442-1455. [CrossRef] [PubMed]

55. Chen, D.-Y.; Lan, J.-L.; Lin, F.-J.; Hsieh, T.-Y. Proinflammatory Cytokine Profiles in Sera and Pathological Tissues of Patients with Active Untreated Adult Onset Still's Disease. J. Rheumatol. 2004, 31, 2189-2198.

56. Priori, R.; Barone, F.; Alessandri, C.; Colafrancesco, S.; McInnes, I.B.; Pitzalis, C.; Valesini, G.; Bombardieri, M. Markedly Increased IL-18 Liver Expression in Adult-Onset Still's Disease-Related Hepatitis. Rheumatol. Oxf. Engl. 2011, 50, 776-780. [CrossRef]

57. Conigliaro, P.; Priori, R.; Bombardieri, M.; Alessandri, C.; Barone, F.; Pitzalis, C.; McInnes, I.B.; Valesini, G. Lymph Node IL-18 Expression in Adult-Onset Still's Disease. Ann. Rheum. Dis. 2009, 68, 442-443. [CrossRef]

58. Maeno, N.; Takei, S.; Imanaka, H.; Yamamoto, K.; Kuriwaki, K.; Kawano, Y.; Oda, H. Increased Interleukin-18 Expression in Bone Marrow of a Patient with Systemic Juvenile Idiopathic Arthritis and Unrecognized Macrophage-Activation Syndrome. Arthritis Rheum. 2004, 50, 1935-1938. [CrossRef]

59. Sugiura, T.; Kawaguchi, Y.; Harigai, M.; Terajima-Ichida, H.; Kitamura, Y.; Furuya, T.; Ichikawa, N.; Kotake, S.; Tanaka, M.; Hara, M.; et al. Association between Adult-Onset Still's Disease and Interleukin-18 Gene Polymorphisms. Genes Immun. 2002, 3, 394-399. [CrossRef]

60. Sugiura, T.; Maeno, N.; Kawaguchi, Y.; Takei, S.; Imanaka, H.; Kawano, Y.; Terajima-Ichida, H.; Hara, M.; Kamatani, N. A Promoter Haplotype of the Interleukin-18 Gene Is Associated with Juvenile Idiopathic Arthritis in the Japanese Population. Arthritis Res. Ther. 2006, 8, R60. [CrossRef]

61. Park, J.H.; Kim, H.-S.; Lee, J.S.; Kim, J.J.; Jung, K.-H.; Park, Y.-W.; Yoo, D.-H. Natural Killer Cell Cytolytic Function in Korean Patients with Adult-Onset Still's Disease. J. Rheumatol. 2012, 39, 2000-2007. [CrossRef] [PubMed]

62. Yasin, S.; Solomon, K.; Canna, S.W.; Girard-Guyonvarc'h, C.; Gabay, C.; Schiffrin, E.; Sleight, A.; Grom, A.A.; Schulert, G.S. IL-18 as Therapeutic Target in a Patient with Resistant Systemic Juvenile Idiopathic Arthritis and Recurrent Macrophage Activation Syndrome. Rheumatol. Oxf. Engl. 2020, 59, 442-445. [CrossRef]

63. Gabay, C.; Fautrel, B.; Rech, J.; Spertini, F.; Feist, E.; Kötter, I.; Hachulla, E.; Morel, J.; Schaeverbeke, T.; Hamidou, M.A.; et al. Open-Label, Multicentre, Dose-Escalating Phase II Clinical Trial on the Safety and Efficacy of Tadekinig Alfa (IL-18BP) in Adult-Onset Still's Disease. Ann. Rheum. Dis. 2018, 77, 840-847. [CrossRef] [PubMed]

64. Kiltz, U.; Kiefer, D.; Braun, J.; Schiffrin, E.J.; Girard-Guyonvarc'h, C.; Gabay, C. Prolonged Treatment with Tadekinig Alfa in Adult-Onset Still's Disease. Ann. Rheum. Dis. 2020, 79, e10. [CrossRef] [PubMed]

65. de Jager, W.; Vastert, S.J.; Beekman, J.M.; Wulffraat, N.M.; Kuis, W.; Coffer, P.J.; Prakken, B.J. Defective Phosphorylation of Interleukin-18 Receptor Beta Causes Impaired Natural Killer Cell Function in Systemic-Onset Juvenile Idiopathic Arthritis. Arthritis Rheum. 2009, 60, 2782-2793. [CrossRef] 